\title{
pÿChildren s Agency in Translocal Roma Families
}

\section{Enache, Anca}

Palgrave Macmillan

2018

pÿEnache , A 2018 , Children s Agency in Translocal Roma Families . in L Assmuth , M Hakkarainen, A L \& P M Siim (eds), Translocal Childhoods and Family Mobility in East and North Europe. Studies in Childhood and Youth book series (SCY), Palgrave Macmillan, Basingstoke , pp. 193-216 . https://doi.org/10.1007/978-3-319-89734-9_8

http://hdl.handle.net/10138/326214

https://doi.org/10.1007/978-3-319-89734-9_8

acceptedVersion

Downloaded from Helda, University of Helsinki institutional repository.

This is an electronic reprint of the original article.

This reprint may differ from the original in pagination and typographic detail.

Please cite the original version. 


\section{Children's Agency in Translocal Roma Families}

Anca Enache

\section{Introduction}

On a sunny morning in September 2014 I was walking through the railway station in Helsinki, Finland with Mandica, aged 26. She was on the phone, conversing and fighting with her sixyear-old daughter: "Why don't you want to listen to me? You should have stayed where we left you. I told you that your father and I will come back soon”. Just three weeks before coming to Finland together with her husband, Mandica arranged with her sister that her two children, a daughter and a son, would stay at her family's place. It was agreed that Mandica would support her sister's household with money while the sister looked after the children. She moved the children to the other house before leaving for Finland, sending with them dry food ingredients and clothes. Today she was informed that the daughter had left from her aunt's place. The sixyear-old had returned to her parent's house, which was located not far away. The daughter had a conflict with her cousins and simply left. She called her mother afterwards informing her that she would not go back, but stay instead at her parents' house. She said to her mother that a female neighbour could look after her. (Enache field notes, September 2014.)

In this chapter I discuss Romanian Roma children's lives and agentive practices in particular times and places in Romania and Finland, in the context of family migration and translocal practices. Temporary adult migration, or the relocation of children in the context of family migration, have an effect on what the children do, with whom, in which places, and their general possibilities to "negotiate and participate in the construction of their daily lives" (Jensen and McKee 2003, p. 1). I highlight how children focused on negotiating and building diverse types of relationship with each other and with adults (Stack 1997). When parents are geographically separate, taking over adult's roles was an important means of children developing a sense of themselves as subjects to be respected by family members and other adults. Working and contributing to the household and their own needs are important activities for children's agency, 
as they instil meaning to what they do (Dyson 2014, p. 3). On the other hand, work constraints imposed by parents and other adults force children to implement strategies to develop work practices that accommodate their own desires and needs. The chapter is centred on the way Romanian Roma children instil meaning and negotiate their relationships, what they do and how they work in a translocal context.

I approach children's agency as a process of 'becoming' (as defined in Chapter 1 in this volume), located and constrained in time and space and by children's relations with other people, cultural and social practices, institutions, objects, environments and by their own memories, knowledge and bodies. I see children's agency as not always being about gaining autonomy, but as being about building relations of interdependency with family members, friends and surrounding places (Dyson 2014). Agentive capacity is entailed not only in those acts that resist norms but also in the multiple ways in which one inhabits norms (Mahmood 2005, p. 15). I develop this argument by discussing how the Roma children I met abide by and reinforce the norms of the adults and of their communities, while at times striving for autonomy and advancement of their own goals. In the context of the Roma children I worked with it is also important to stress the limits to their agency. Race, class, age, gender, citizenship status when abroad and inequalities shape children's actions in the context of family migrations. For example, the scarce economic conditions of the families emphasise limits of agency, but also the extraordinary resourcefulness and skills that some of the children develop to make money and provide for their families.

The emerging body of scholarship has been preoccupied with the current mobilities of Eastern European Roma in Europe. The main themes of research have so far been: the politics of states and state actors related to Roma migrants (Sigona 2005), the discourses of media and organisations relating to migrants (Benedikt 2010), and the interaction between migrants and civil society actors and the practices and experiences of mobilities (Grill 2012a). However, there has been a lack of academic engagement with Roma children's lives and practices in the context of translocal mobilities (for exceptions see Lulle and Assmuth 2013). Children's everyday lives in Eastern European locations have not been studied much, either (Blazek 2011). Vrăbiescu (2017) examined the relationship between municipal policies and practices and Romanian Roma families and children in the context of Catalonia, revealing how children are targeted and treated 
especially in child protection cases. By using the children's rights paradigm and the 'best interest of the child' model, officials oblige families and children into forced return mobility. In most studies Roma migrant children and their families are discussed as the target of policies, while little attention is given to their agentive practices relating to the policies, or family relations and activities. Wider research into family and child mobility, constructs children as passive dependents and overlooks children's own experiences and perspectives (Ackers 2000). Children have been generally treated in childhood studies as well as in public discourses as "adults in the making rather than children in the state of being” (Brannen and O'Brien 1995, p. 730).

In addition, scholarship has taken for granted the marginalised political, economic and social position of the Roma, while children are approached through themes such as health and social wellbeing and segregation, for example when part of the education system. Children are also discussed as passive actors whose lives and experiences are governed by adults or the system surrounding them. Roma migrants and the Roma more extensively are often labelled as marginal (Engebrigtsen 2007, p. 11) or victims (Yuval-Davis et al. 2017) since very often they are not at the centre of what are considered political, economic and social resources within nation states. This is because they might be facing poverty, or have a low level of education or high unemployment. However, individual's subjective understandings and practices of agency do not always relate to such socio-economic determinants.

This chapter is based on three individual stories about particular Romanian Roma children and their households. All of them have interacted with translocal mobility by moving, or by the mobility practiced by their family members. As individual stories they illustrate the key points of the chapter, diverse key aspects of children's everyday practices and agency. Nevertheless, I have tried to maintain some sense of wholeness so that each story can also be read as an individual portrait that reveals the interweaving of various facets in the children's lives. The stories are located in three different geographical locations, two localities in Romania and one in Finland, in Helsinki, each of them having their particular social and political context at the time of the study. The third story is exceptional as it discusses childhood agency through the narrative of an adult woman. This case reflects continuity between a child's and an adult's agency, as a child's agency is not only about age but also about many other positions, such as gender and 
ethnic belonging, that shape child and adult lives over time (see also Chapters 9 and 10 in this volume).

\section{Romanian Roma and 'making Europe'}

Transnational mobility to different European countries has been among Romanian Roma economic and social strategies after the collapse of the socialist regime in 1989. As the socioeconomic conditions worsened, and ethnic discrimination continued to be part of many Roma lives in Romania, leaving for Europe provided an advancement path that would bring income and social improvements, as well as higher economic status for some households (Grill 2012b). Some Romanian Roma have practiced transnational mobility for a generation already, while others have started to go abroad more recently, once Romania gained visa liberalisation with the European Union and subsequently joined the EU in 2007.

This chapter talks about Romanian Roma whose lives have a translocal dimension and a connection to Finland. Among families studied at least one household or family member, usually adult but also children, went temporarily to Finland starting from 2008. These families have also had a history of mobility to other European countries, as well as short periods of mobility to other locations in Romania. Most of the people involved in the study are engaged in the capital city, Helsinki, with income generating activities such as selling a street magazine, collecting bottles, or working in temporary jobs. The income can be characterised as insecure because it depends on the ability of each individual to trade things, to ask for help (to beg), or to find temporary employment. Working requires many hours on a daily basis- (Tervonen and Enache 2017.)

Most of the families live in informal housing in Helsinki, meaning that they do not rent a place but sleep in abandoned houses, forests or rent a sleeping place informally in someone's apartment. Because of these housing circumstances the adults usually prefer to leave the children in Romania, and bring them to Finland only when they have secured at least some kind of sleeping arrangement in a house. In Finland the household and family structure that would provide informal care for the children is usually missing. 


\section{Ethnographic encounters: learning to walk with children}

The chapter is based on ethnographic material collected between 2012 and 2014 in three locations, two small villages in East Romania, and in Helsinki, Finland. The multi-sited fieldwork approach (Marcus 1995) was not something planned when we started our work in Helsinki together with researcher Airi Markkanen, but rather an outcome of how children's practices and agency were performed in the context of interconnected family and geographical settings (cf. Chapter 4 in this volume).

In the first story, some of the children had been in Finland previously, although at the time of our research they were already living in Romania while their parents and adult siblings travelled between the two countries. The parents decided to take their children to their home country as they were afraid that child protection officials would take the children into custody because they were not able to prove to them that they had a formal income and accommodation. (Tervonen and Enache 2017.) Airi Markkanen and I met these children in their adult sibling's household in a Romanian village, and we engaged in everyday activities with them.

We met the two girls and their mother, who are at the centre of the second story in Helsinki, at the premises of a community centre. This place was not open to the centre's clients when the meetings were organised. It served as a physical meeting place since the mother wanted to meet us outside of the apartment where they lived in Helsinki. In addition, the daughters and the mother were not very familiar with Helsinki and were not active in navigating the city. In these meetings we used drawing as a way to break the ice and involve the girls, especially the older one, in our discussions. This proved to be a good method with the older girl, as she had experience with, and even enjoyed, drawing. I asked her to draw her favourite places in Helsinki and her best friends. Drawing places was however not easy for her, so we were mainly talking on this theme, while drawing her friends and describing the drawing was much easier. I used both the drawings and the discussions as data for this chapter. 
I met Daniela, aged 40, on several occasions in Helsinki, in different public places such as fast foods and cafeteria. Daniela was very eager to talk about her strategies to succeed in life, especially by linking her present achievements through what she did as a child and young women. The data presented are based on her adult narration of her childhood agency, narration of the past that was very much connected by the teller to her present and future life.

My access to the children was mediated by adults, the parents or adult siblings of the children, and even more often by the fathers as "gatekeepers" (Heath et al. 2007). The adults did not ask the children if they were willing to participate but made the decision on the basis of their own assessment: if I had a history of proper behaviour towards them in the past I was given access. I knew many Roma adults in Helsinki since I worked as a community worker and expert with the civil society that provides services and advocacy among Eastern European migrants in Helsinki. The collection of data for this research was kept separate from the work conducted for the civil society sector, but of course this last position influenced my accessibility to the field and interactions with the informants. Many adults had positive memories on our past encounters, which influenced their willingness to engage their families and children in the study. I was however unknown to all the children I met.

Most of the encounters with children happened in the presence of their parents or other adult siblings. Even when the parents did not ask the children's consent, I tried during the interaction to tell the children about myself and to be very sensitive to what they wanted to do. For example, with the group of children that I met in the Romanian village, some children, especially the boys, simply preferred to stay outdoors and engage in other activities in the village than to talk with us, since they thought it was boring to spend time with us.

Mayall (2000, p. 121) points out that an "adult researcher who wishes to research with children must confront generational issues" since children are very used to having everyday events and experiences dominated by adults. I adopted the least adult role (Thorne 1993; Mayall 2000), meaning that I tried to participate in the children's everyday lives as far as possible in the same way the children did, or at least not in the way the adults surrounding them did. I tried to differentiate myself from the standard adult roles. I opted for this, as I didn't want to reinforce 
adult-child power relations, while I was also aware that the adult role imposes barriers to getting close to the children. This meant that I tried to show no concrete power. I did not involve myself in guiding the children and I took no stands on their practices. This was ethically difficult when children teased or bullied their cousins because of their appearance and skin colour for example. On the other hand, adults from their community were almost always present so there was no space for my guidance as an adult. Some of the children clearly took me as the least adult at times, since I didn't fit into the adult social and cultural categories and practices they were used to: I looked young, I joined them in whatever they were doing and I didn't have the authority they were used to. On the other hand, I was associated with their parent's worlds since it was the parents who had introduced me.

I was the 'other adult' also because I was non-Roma in the eyes of the children and their families. Children had their own understandings of the boundary between Roma and non-Roma, developed from their families or through their own interactions with non-Roma children and adults. The children whom I met in Dry Valley had had some sort of particularly negative past experiences with non-Roma, with Romanians in the village. Romanian adults or children called some of them names such as "blackish" or "Gypsy" in the past. However, I was identified as the 'good' non-Roma because their parents accepted me and brought me into their house. My 'nonRoma' position also created possibilities. I was not identified as a typical adult from the community. This meant that the children felt more open to discuss issues in my presence that were considered taboo in the community, as well as things that their parents were very severe about. That was the case with practices and thoughts about sexuality and sexual relations. For example, one girl developed an intimate confidence in me once we got to know each other, and wanted to talk to me about a boy that she was interested in.

I used the approach established by Christensen (2004, p. 170) in doing fieldwork among children: "fieldwork as a practical engagement with local cultural practices of communication". All children spoke in the Romani language inside the family and in household circles, while the older ones also spoke Romanian. I spoke Romanian with the older children, but with the younger children our communication was limited to a few words. However, what proved to be more important was observing and engaging with children's actions in specific contexts and at specific 
times, as well their use of language, expressions and body language. This supported for example my understanding of the power structures between them as being connected to specific situations. As I gained trust and became integrated into some of the children's lives, I started to be more aware of the children's views, of the issues they would like to talk about and the issues about which they wanted to remain silent. This meant that I had to become very aware of sharing individual children's views with different audiences.

\section{Caring and being cared for}

"Out, now all out! Why do you all come inside, what is here, don't you have homes or mothers?" Rodana screamed and chased away the crowd of kids of various ages that had gathered inside the room at her family's place (because they heard that there were visitors). Dana, Rodana's older sister was also active in chasing them out, using the expressions and common interjections of the older women in the community: "Why are you always in between the legs of others, can't you play outside with the other children?" The room started to empty little by little. Some of the closest cousins remained to hang around in the small yard in front of the building. Dana continued to wipe the clay floor, while Rodana tried to make us, the guests, feel comfortable. She directed us to sit on the sofa together with her father and brother, while she put on a small table the goodies that another sister brought from the shop: two bottles of Coke, biscuits and sweets. The sisters and some of the cousins hurried around the table so as not to miss their share. (Enache field notes, June 2012.)

Like Dana and Rodana the other children in their household were also very much relating what they did and said to other children and adults. Children presented themselves and others as being someone's daughter, cousin or sister. During my fieldwork period I could hear them using such names especially for the people who formed the same physical household, as well as for other people who lived outside of it. In this section I explore the Roma children's cultural framework of thinking, living and practicing relatedness, taking into consideration their social networks and the possibilities and constraints these networks might present to different children, through the specific case of the household that Dana and Rodana were part of. Following Dalgas and Olwig 
(2015), I understand family relations in terms of ideas and practices of relatedness, practices that involve mutual support, solidarity and conflict.

Dana and Rodana's family lived with four other families including uncles, wives and children, which meant that family relations were very intense; their everyday practices were significantly affected. The Roma create general relatedness based on the ideology of patrilineal descent, which makes the relations between brothers special (Stewart 1997) and stresses the role of males as household heads. The boys in the family are expected to remain close to their parents once they get married, while girls follow their husbands to the husband's family. From this follows the gender differentiation between the sons' children, who will continue the family and stay close, and daughters' children, who will leave the household and become part of another family. The grandparents, as the oldest in the family, represent the main authority, followed by the eldest son and his family, in this case Dana and Rodana's father. Children were expected to respect, obey and assist older siblings with the everyday work. Both children and adults called the siblings sharing the household as well as those living outside it 'familia', the family (Engebrigtsen 2007).

The household consisted therefore of a considerable number of children, twelve altogether, who shared some of the house with their relatives; Dana and Rodana commonly shared their room with their brothers and sisters. If the relationships inside this household derived from Roma social organisation of family relations, the housing arrangements themselves can partly be attributed to the economic circumstances of the families. All family members in this specific household generated income through informal labour locally or in Finland, or through commodity exchange. The women of the house particularly emphasised that they would prefer not to live under the same roof but build separate homes where they could live with their husbands and children. They complained that there were too many children in the same place and too many conflicts between the children, as well as between the adult siblings. On the other hand, as most of the adults were going abroad for shorter or longer periods, all the adults were very seldom together in the house in Romania.

Children and unmarried youth performed and were involved in various family duties from the earliest age. Girls looked after their younger siblings and assisted their female siblings when 
their mothers were abroad with tasks such as cooking, cleaning and generally taking care of the household. Boys spent more time outside and accompanied the older men in their work and other activities. Although children's involvement with family tasks was not strictly gendered, the gender division was very much visible in one of the central dynamics of the children's family live: the complex patterns of care, which I will refer to through girls' and women's perspectives.

Dana, fifteen years old, and Rodana, twelve years old, took practical care of their three younger sisters when their parents were in Finland or abroad. Caring for the younger sisters meant assisting them eating or washing themselves, or accompanying them when they went to play outside where the traffic could be a threat or they could get in conflict with other children. When their father was at home, they were still involved with many of these tasks, while when the mother was at home, they assisted and learned from her. The grandmother in the family, or even more commonly one of the children's aunts, was the adult supervising them when both parents were abroad. She was the one to receive the money sent from the parents and to purchase food for the household, and she would make sure that the older girls behaved according to the social and moral rules of the family. The adults who were abroad paid the responsible adult at home for her provision of care and supervision, and in this way resources were pooled in order to provide the necessities for the children and adults who formed the household. Therefore, food was provided for all children, even when one of the families had no money. Resources were however not shared equally with each nuclear family, and their children's, resources varying according to that family's possibilities to generate income.

The children in the household therefore spent large parts of their days caring or being cared for, socialising and interacting among themselves or with other children in the neighbourhood. The relationships of care as embedded in the family relations are therefore very significant in children's everyday practices and as possibilities for agency. The children were of different ages and both genders, as well as from different social and power positions inside the family structure and in the community and village. Dana and Rodana, as older sisters, were delegated adult's authority in front of the younger siblings when the parents were abroad. In their practices, they were aware of their authoritative power because of their ages and the fact that the parents needed their labour. The older girls were also conscious that the adults, especially the mothers, needed 
them to take care of the household when they couldn't, so, for example Dana exclaimed when she was angry with her mother: "She doesn't want me to get married because I have to take care of her children".

Younger children were aware that they had to be friendly and collaborative whenever they wanted to get something from the older sisters; they even pretended to be subordinate and showed humility before asking for something. In other circumstances the younger children engaged in plots and coalitions in order to escape some of the rules imposed on them, or playacted in some way to get access to resources. That was the case with taking food or sugar from the fridge or getting money to buy things from the shop.

The relations of care also involved daily conflict between the older and younger children. There was name-calling that was intended to reduce the authority of the older sisters and to justify the children's disobedience, such as "you are ugly", “you are stupid”, "you are not our sister". The last insult is something that the younger sisters used to annoy Dana, since she was not part of the father of the family's kin group, but his step-daughter. Since adults used this framing in relation to Dana, the children learned it and used it strategically during conflicts. The children were very aware of the social and cultural hierarchies that existed among their siblings and actively used them as well as building new ones or subverting existing one. Very often they called the parents abroad to seek justice and complain about each other, obliging the parents to re-establish order by phone. I often heard such conversations during fieldwork among parents in Helsinki.

The practices and relatedness of the children in the context of caring relations were not only about structured care relations and authority, but also very much about spontaneous practices and engagements in which the older children also acted as friends (Punch 2005). I started this chapter with the image of Dana and Rodana taking their position of authority and the care tasks they performed for the other children seriously. However, quite often when the younger children were doing something that interested Dana and Rodana, for example playing a specific game or going somewhere, one could see different interaction and friendship patterns emerging. 
Both older and younger children navigated these different positionalities of caring for and caring with. At times the care commitments were very structured, for example in the case of the older girls like Dana, while at other times they were very spontaneous and derived from the family's common practices and understandings of relatedness. Sometimes children complained about having to take care of other children, while in other circumstances it was just something taken for granted, embedded in their everyday lives.

\section{Meaningful everyday places}

The yellow pencil moved quickly over the page. A human figure with long black hair was developing little by little. After working on the clothing, seven-year-old Denisse, the author, isolated the main person in the sketch by drawing a gold-ish circle around her. "Sonia, she is Sonia, my best friend." Denisse's mother explains to me, amused: "You should see them; they are so funny talking on the phone. Denisse finds a corner in the house and talks with Sonia from there, in privacy. They have their own secrets". At times Denisse says: "I want Sonia to come here, to show her the playground", while at other times she asks her mother when they would go to Romania to see Sonia. She navigates through places, imagining future activities with Sonia: she will show her new things, or engage with some of the funny things they used to do together in Romania. For my first meeting with Denisse, her two-year-old sister and their mother, I brought coloured pencils and paper. I imagined that drawing might interest the two girls more than my conversation and so it was. I also thought that drawing could be a way to better represent and imagine things. The mother again was very eager to take the opportunity to talk with someone from Romania. (Enache field notes, first meeting with Denisse.)

\section{<FIGURE 8.1 INSERTED ABOUT HERE>}

Figure 8.1 Drawing by Denisse (7). Drawing of close friend who lives in Romania, located in the centre of the picture. The grandmother, who lives in France, is on the left and Denisse herself on the right.

During our meetings Denisse, her sister and her mother often talked about how there was a range 
of places and place related issues in Romania and in Finland that had an influence on their everyday lives in Finland. For example, Denisse talking with her friend Sonia in a specific, private corner was not accidental. Denisse wished to have privacy and talk in peace with her friend and did so by creating a space of their own. It was a struggle for her to create such opportunities for privacy because the apartment where she lived was overcrowded and was composed of one big room, a kitchen and a toilet. This section explores agency in relation to the places that were part of children's experiences or discussions. Children's agency is practiced in key places where they can fulfil their wishes and resists adult forms of spatial control.

Denisse, seven, talked about how much she enjoyed her time in Romania because she could easily access the outdoor environment just by stepping out of the house. At the gate of the house where they lived, young children and mothers gathered in the evenings and at weekends to pass the time. The gate was one of the places where Denisse did things with her friend Sonia, as well as with other children, while her mother chatted with the women of the village. In contrast to this she described the place where they live in Finland, which is located "up" in an apartment building from where she cannot go outside without being accompanied by one of her parents. Denisse, her sister and her mother had moved to Finland only three months before, a relocation decision in which Denisse was not involved as she was considered too young. As Denisse's mother herself is unsure about navigating the new neighbourhood, Denisse is accompanied everywhere, even to school and to the playground. As the family moved from a village environment that they were very familiar with, to a large urban environment, the parents are concerned about the movement practices of the girls and so restrained them. In fact, the streets in Helsinki seemed to be for the family a sexualised and gendered space of danger and threat. The father is the only one who navigates the city - the mother and girls will only go outside their immediate neighbourhood when he accompanies them.

Denisse also talked about being 'bored' at home, and her wish, as an alternative to this, to call Sonia in Romania. Denisse lived with her sister, mother, father and an elderly Finnish woman who was the owner of the house. The family could not afford to rent their own apartment, since only the father was working although this did not generate enough income to rent an apartment. The flat was therefore an adult dominated place, especially because the mother often warned the 
girls that they should not make any noise or disturb the old woman when they were playing. This indoor environment provided few opportunities for social interaction as it was dominated by adults. Her sister was only two years old and very often Denisse found her too young to play with. Denisse's boredom derived from the fact that she had no possibility to find an alternative place to socialise while at home adults imposed many restrictions on the place where they lived.

When Denisse talked about longing 'to get out' and back to Romania, she was drawing and talking about some of the places and practices that she likes in Helsinki. The playground next to their house was one of the places where she liked to go, so she described the equipment in detail, partly also because it was different from playground equipment in Romania. Denisse's mother said that they went to the Helsinki playground often, since it was still warm outside. Season was important for this place and practice, as well as more generally for the family's everyday rhythms. The mother tried to have the children play outside in the immediate neighbourhood, as the apartment where they lived was small and crowded.

\section{<FIGURE 8.2 INSERTED ABOUT HERE>}

Figure 8.2 Denisse's drawing on her favorite places and things in Helsinki: picturing her and her sister at the playground next to their house, its infrastructure and trees and the slot machine in the central railway station.

Another place that the family and Denisse talked about was the central railway station in Helsinki. That was the place where all of them, the mother, father and two daughters, went on Sundays to gather and meet other Roma migrant families living in the city. The children were taken there by the parents to meet the other children and siblings, for example Denisse's cousins. The aspect of the railway station that she wanted to talk about was a slot machine that she is allowed to play games on sometimes. This is her father's hobby and at times she is allowed to play as well. In this way and in this place this practice provides her with a way into her father's world and into the world of adults. Denisse's sister did not get to play on the slot machine, marking her as a child, and signifying a difference between her and Denisse. In addition, Denisse's act of wanting to have personally significant places outside the apartment could be 
interpreted as a 'source of power' stemming from the fact that her present possibilities for everyday activity in Finland were very limited, a feeling that was amplified by her recent memories of Romania.

During our meetings Denisse did not talk about the journey to Finland. She did however talk about several significant everyday journeys in Finland, as well as about imaginary journeys to Romania to the places where she spent time with Sonia, as described above. Once, she even took us to a place in France that she had never visited - she imagined it because her maternal grandmother had once lived there. Places very much intersected with things, seasons and people that were significant for her now or would be in the future. Places limited or enabled her agency, her possibilities to decide about her own physical mobility or her ability to negotiate and perform friendships. She did not mention the school at all, before we asked her despite the fact that she attended school daily. However, by the time of the interview she had been enrolled in school in Finland only for one week, and her mother told us that she "doesn't have friends yet and doesn't understand the language". Because of that, the school was still not a place that would enable her to have a social life locally.

\section{"God didn't leave me, I lifted myself up"}

Daniela was upset when I met her today. She had had a fight with her friend. The two women, both in their fifties, travelled together from the same town in Romania to Helsinki, where they did many everyday things together. This week they separated, as the friend said to the other relatives in the city that "[although] Daniela has tried hard all her life it is all in vain, she is and she will stay poor". This made Daniela very upset as the way she sees it her life has been about luck and working hard and this is what has elevated her. Therefore, today more than ever she feels that she wants to tell me a story about her childhood, as that is "a story without lies or stupid things, but with true and big things". (Enache field notes, July 2016.)

The encounters with Daniela were in some way exceptional. Very often she talked about the continuities between her childhood and her present adult life, especially by emphasising how work and success achieved as a child shaped her subjectivity, sociality and imaginary both then 
and now. "God didn't leave me, I lifted myself up", was the phrase that she used before starting to talk about each significant moment in her life. The wording revealed precisely how "luck" and "God's help" were constant and very similar in her life as a child and as an adult, although the context was different. She did not separate practices of childhood agency from adult practices, but rather presented them as lifelong practices. Her narration oscillated between luck as a key element to her success, and hard work, a practice she learned and developed actively during her childhood and which contributed to her success in life. This section is an account of Daniela's work in her childhood home in Romania, unfolding her childhood agency through the lens of the different work and responsibilities that she had.

Daniela started to make money when she was nine years old. Back then she lived with her aunt's family as her parents had separated and the mother remarried. The aunt noticed that she was a hard working girl. She helped with care of her aunt's child and other household chores. The aunt was making money by trading clothes and other goods to people in the area and in neighbouring localities. She thought that Daniela would be a talented trader so she started to take her when she went to sell her goods. Daniela, like other children in the neighbourhood, was very determined to make money and to get things because it gave her the possibility to support her grandmother as well as to purchase goods for herself.

She remembers that she started by selling chewing gum and cigarettes. This was during the Ceausescu era in Romania so there were shortages of goods. Daniela's aunt bought products from dealers and Daniela sold them on. Her work and success very much depended on the surrounding social environment, including the needs of the people. This is often the case with the economic practices of Roma communities. This form of work required flexibility and mobility. The personal ability to cultivate customer relationships was also very important. Daniela's aunt taught her some skills, while Daniela was also active in cultivating these abilities. She was perceived as a beautiful young woman who looked older then she actually was, which made her successful in trade. In time, she learned how to talk with the clients improving each day.

She was not the only young trader in her community and there were friendship and conflict relationships between the child traders. At times they gathered and talked about the day's 
experiences, sharing successes or bad experiences. They made fun of the clients and talked about the tricks they used to sell more. Some traders were better than others and their relationships were hierarchical and competitive at times, although there was some fun as well. For example, Daniela talked about subjects that were taboo in her family, such as romantic relationships, with the girl traders' group (Dyson 2014). The group was a forum where they could smoke cigarettes both because they were outside the family household in a different environment, and because they could afford to buy cigarettes.

Daniela was also very active in deciding how she used the money she earned. She allocated money for the "common good" of the family as well as for her own purposes. She contributed to the household needs by buying food or wood. For example, she was very interested and active in buying clothes and things that made her look beautiful, especially when she was over twelve years old. Being able to buy beautiful clothes was an important way to gain status and power for young women living in the community.

Making money was very significant for Daniela during her childhood and youth since this provided her with a sense of self-respect and honour in the community. Sharing is an essential moral value that defines Roma family relations and interactions, and more generally Roma everyday culture (Stewart 1997). Work and the provision of resources give access to the sharing practices of the community. The economic role of the women in Daniela's family was very much linked to the local context, but also to the gendered practices of the Roma in general. Sharing is also related to honour and a strong moral obligation to be self-sufficient. As Engebrigtsen (2007, p. 77) demonstrated in her ethnography made among one Roma community in Romania, families are morally valued when they manage to be self-sufficient. As with Daniela's aunt, the Roma women and young girls in their neighbourhood were responsible for the daily provisioning of the families. Being hard-working and providing for one's family makes a respectful woman and it is often Roma women and girls, rather than Roma men, who practice trading activities (Okely 1975).

Working also helped Daniela to overcome the stigma that was linked to her mother in the community. Her mother was known and blamed for not being good at making money; she was 
good "only to get married to new husbands". When she was ten Daniela too criticised her mother for not being able to provide money for their family. "I was the one to provide for grandmother and sometimes even for my mother too", she explained to me. This also provided her with power over her mother, as she realised that her siblings and others in the community accepted the fact that she did not need to do what her mother said.

\section{Conclusion}

This chapter explored Roma children's practices as they relate to a wide range of people, things, places, social and economic regimes and cultural practices present at particular moments in children's lives. The analysis was based on ethnographic material grounded in particular translocal settings: a family household in East Romania, a community centre in Helsinki and the imaginary of childhood memory. Economic instability, ethnicity and gender shaped these children's lives in ways that are likely to be more constraining than many other childhood settings. The use of diverse cases was essential to reveal how children's agency is exercised and experienced in different places and times.

A key contribution of my work to an understanding of children's agency has been to demonstrate the importance of Roma children and youth in the practices of translocal mobility. In Romania the children worked hard to run their households according to familial and social norms, while also claiming a space for their subjective inputs. A sister was no longer a sister if she disobeyed the rules of the family while the parents were abroad. Younger sisters could adopt this adult discourse on family norms, while at the same time willingly spending time with the rejected sister. When the children went abroad with their parents they worked hard to adapt to the new circumstances, attaching their own meanings to new environments, things and people.

What also materialises from my account is the energy that children and youth put into building familial and social relations, and into learning the jobs that generate an income, with a view to securing their future. Roma children and youth built agency not by becoming independent but through the effort of learning the social norms and developing relationships with their familial networks and the social environment, as exemplified by the sharing relations that characterise 
many Roma households and families. The social environment is a source of work and money, so the relationship with it is of particular importance. Managing translocal settings is part of imagining and preparing for the future, therefore one could say that part of children's agency was about connecting to dominant structures and norms.

Finally, the third case presented here emphasised the many links between personal practices of agency during childhood and during adult life. In her narrative Daniela underlined the continuities throughout her life that affected and built her agency. However, as there are always ruptures and continuities, it will be interesting to further explore in other cases and contexts how agency is formed, narrated and made sense of throughout a person's life, starting from childhood.

\section{References}

Ackers, Louise. 2000. "From 'Best Interests' to Participatory Rights: Children's Involvement in Family Migration Decisions.” Child and Family Law Quarterly 12 (2): 167-184.

Benedikt, Stefan. 2010. “Harming 'Cultural Feelings': Images and Categorisation of Temporary Romani Migrants to Graz/Austria.” In Multi-Disciplinary Approaches to Romany Studies, edited by Michael Stewart and Márton Rövid, 71-88. Budapest: Central European University Press.

Blazek, Matej. 2011. "Place, Children's Friendships, and the Formation of Gender Identities in a Slovak Urban Neighbourhood.” Children's Geographies 9 (3-4): 285-302. doi:10.1080/14733285.2011.590700.

Brannen, Julia, and Margaret O’Brien. 1995. “Childhood and the Sociological Gaze: Paradigms and Paradoxes.” Sociology 29 (4): 729-737. 
Christensen, Pia Haudrup. 2004. "Children's Participation in Ethnographic Research: Issues of Power and Representation." Children and Society 18 (2): 165-176. doi:10.1002/chi.823.

Dalgas, Karina Märcher, and Karen Fog Olwig. 2015. "Local and Transnational Care Relations: Relatedness and Family Practice among Au Pairs in Denmark." Global Networks 15 (4): 469-484. doi:10.1111/glob.12074.

Dyson, Jane. 2014. Working Childhoods: Youth, Agency and the Environment in India. Cambridge: Cambridge University Press.

Engebrigtsen, Ada I. 2007. Exploring Gypsiness: Power, Exchange and Interdependence in a Transylvanian Village. New York and Oxford: Berghahn Books.

Grill, Jan. 2012a. "'Going up to England': Exploring Mobilities among Roma from Eastern Slovakia." Journal of Ethnic and Migration Studies 38 (8): 1269-1287. doi:10.1080/1369183X.2012.689187.

Grill, Jan. 2012b. “'It's Building up to Something and It Won't Be Nice When It Erupts': The Making of Roma/Gypsy Migrants in Post-Industrial Scotland." Focaal - Journal of Global and Historical Anthropology 62: 42-54. doi:10.3167/fcl.2012.620104.

Heath, Sue, Vikki Charles, Graham Crow, and Rose Wiles. 2007. "Informed Consent, Gatekeepers and Go-betweens: Negotiating Consent in Child and Youth-Oriented Institutions." British Educational Research Journal 33 (3): 403-417. doi:10.1080/01411920701243651.

Jensen, An-Magritt, and Lorna McKee. 2003. "Introduction: Theorizing Childhood and Family Change." In Children and the Changing Family: Between Transformation and Negotiation, edited by An-Magritt Jensen and Lorna McKee, 1-13. London and New York: RoutledgeFalmer. 
Lulle, Aija, and Laura Assmuth. 2013. "Families on the Move in Europe: Children's Perspectives." Siirtolaisuus-Migration 40 (3): 3-10.

Mahmood, Saba. 2005. Politics of Piety: The Islamic Revival and the Feminist Subject. Princeton NJ: Princeton University Press.

Marcus, George. 1995. "Ethnography in/of the World System: The Emergence of Multi-Sited Ethnography." Annual Review of Anthropology 24: 95-117.

Mayall, Berry. 2000. "Conversations with Children: Working with Generational Issues." In Research with Children: Perspectives and Practices, edited by Pia Christensen and Allison James, 120-135. London and New York: Falmer Press.

Okely, Judith. 1975. "Gypsy Women: Models in Conflict.” In Perceiving Women, edited by Shirley Ardener, 55-86. London: Malaby Press.

Punch, Samantha. 2005. "The Generationing of Power: A Comparison of Child-Parent and Sibling Relations in Scotland." In Sociological Studies of Children and Youth 10, edited by Loretta Bass, 169-188.

Sigona, Nando. 2005. "Locating 'The Gypsy Problem'. The Roma in Italy: Stereotyping, Labelling and 'Nomad Camps'." Journal of Ethnic and Migration Studies (31) 4: 741-756. doi:10.1080/13691830500109969.

Stack, Steven. 1997. "A Comparative Analysis of the Effect of Domestic Institutions on Suicide Ideology." Journal of Comparative Family Studies 28 (3): 304-319.

Stewart, Michael. 1997. The Time of the Gypsies (Studies in the Ethnographic Imagination). Boulder, CO: Westview Press. 
Tervonen, Miika, and Anca Enache. 2017. "Coping with Everyday Bordering: Roma Migrants and Gatekeeprs in Helsinki." Ethnic and Racial Studies 40 (7): 1114-1131. doi:10.1080/01419870.2017.1267378.

Thorne, Barrie. 1993. Gender Play: Girls and Boys in School. Buckingham: Open University Press.

Vrăbiescu, Ioana. 2017. "Roma Migrant Children in Catalonia: Between the Politics of Benevolence and the Normalization of Violence." Ethnic and Racial Studies 40 (10): 1663-1680. doi:10.1080/01419870.2016.1229491.

Yuval-Davis, Nira, Viktor Varjú, Miika Tervonen, Jamie Hakim, and Mastoureh Fathi. 2017. "Press Discourses on Roma in the UK, Finland and Hungary." Ethnic and Racial Studies 40 (7): 1151-1169. doi:10.1080/01419870.2017.1267379. 